IJ§ER

ISSN: 2149-5939
International Journal of Social Sciences and Education Research

Online, http://dergipark.gov.tr/ijsser

Volume: 1(2), 2015

\title{
Effects of Zero Moment of Truth on consumer buying decision: An exploratory research in Turkey
}

\author{
Adnan Veysel Ertemel ${ }^{1} \quad$ Ahmet Başçı ${ }^{2}$
}

Received Date: $01 / 02$ / 2015

Accepted Date: 01 / 04 / 2015

\begin{abstract}
With the advent of Internet that enables always connected consumers and readily available rich information about all types of products, consumer's purchase decision process has been radically altered that accompanies more information seeking activity prior to going to the store shelf. First moment of truth (FMoT) and Zero Moment of Truth (ZMoT) are the concepts coined by practitioners studying important moments in the consumer purchase decision process. First moment of truth emphasizes the critical importance of the in-store experience and the first few seconds when the consumer encounters with the brands on the shelve. The Zero moment of truth highlights the consumer's online research phase that occurs prior to the buying decision. It includes using electronic Word of Mouth (e-WoM) to make more informed decisions. The concept goes back to impulsive purchasing behavior studied in the academic research. This paper lays down the theoretical background of Zero Moment of Truth concept and links it to the existing academic literature. Furthermore, it uses a prior similar research conducted in US market to discover how zero moment of truth effects Turkish consumers' actual buying behavior. The research analyzes the results across different demographic segments. Finally, the results are compared with the prior research.
\end{abstract}

Keywords: Zero Moment of Truth (ZMoT), buying decision process, impulse buying, e-word of mouth

\section{Introduction}

Product purchase decision process starts with being exposed to a stimulus, to various phases, finally to decision phase. The recent developments in Internet and mobile communications technology enabled consumers to have ready access to all kind of information immediately after being exposed to a stimulus. This is made possible especially with rapid penetration of smartphones worldwide. The Social media revolution and exponential growth of user generated content with valuable and credible information about brands by peers is also an important driving force. Practitioners recently coined this new term - Zero Moment of Truth to explain this new phenomenon. Theoretically, this concept has roots in impulse buying phenomenon defined by Stern (Stern, 1962). In the following section literature review regarding impulse buying, stimuli and moments of truth are discussed.

\section{Literature review}

Impulse buying

Impulse buying is a phenomenon that has started to trigger consumer researchers' interest way back in 1950's (Clover 1950; DuPont Studies 1945, 1949, 1959, 1965; West 1951). Rook and Hoch (1985) offered a psychological model of consumer impulse buying episodes. Beatty and

\footnotetext{
${ }^{1}$ Dr., Bahçeşehir University, Social Sciences Institute, ISTANBUL/TURKEY,adnanertemel@gmail.com

${ }^{2}$ Dr., Marmara University, Business Administration Faculty, ISTANBUL/TURKEY, ahmetbasci@gmail.com
} 
Ertemel, A.V., Başçı, A. (2015). Effects of zero moment of truth on consumer buying decision: An exploratory research in Turkey. International Journal of Social Sciences and Education Research, 1 (2), 526-536.

Ferrell (1998) extended the research by exploring the precursors of impulse purchasing and examining how in-store browsing, for recreational and informational purposes, influences impulse purchasing behavior. Recently, Hausman (2000) established that impulse buying is a common method of product selection, in part, because it provides hedonic rewards.

\section{Impulse buying definitions}

The early studies viewed impulse purchasing to be just unplanned purchasing and were conducted with managerial interests in mind (i.e., for the retailers' benefit). The purchase, not the consumer, was investigated. Researchers were solely interested in the pervasiveness of impulse purchasing and recorded it as the difference between shoppers' intended and actual purchases. Seen as an unplanned buying behavior, impulse buying is defined by Engel et all. (Engel et all., 1982) as a buying action undertaken without a problem having been previously recognized or a buying intention formed prior to entering the store.

The definition of impulse buying used here follows from Rook (Rook, 1987). He defines impulse buying as "when a consumer experiences a sudden, often powerful and persistent urge to buy something immediately". Rook mentions that, consumers who plan to buy a product but may not have yet decided which features and brand that they want can also be considered impulse buyers (Rook, 1987).

\section{Categories of impulse buying}

The most accepted categorization of impulse buying is Stern's categorization into four groups (Stern, 1962).

1) Pure impulse buying: the novelty or escape purchase that breaks a normal buying pattern.

2) Reminder impulse buying: this occurs when a customer is reminded of being low on a product or is in need of an item when he/she sees it at the store or recalls an advertisement about the item and a previous decision to buy.

3) Suggestion impulse buying: this occurs when a customer sees the product for the first time and then visualizes the need for it even though she has no previous knowledge about the item. Product quality, function and the like must be evaluated at the point of sale.

4) Planned impulse buying: this occurs when a customer enters a store with the intention of purchasing certain items, but recognizes that he/she may purchase other items dependent upon sale promotions.

Stern's (1962) contribution and categorization of impulse buying is quite significant, because even today most research studies use his concept of impulse purchases as a starting point (Beatty and Ferrell 1998, Rook 1987).

Stern notes that suggestion buying is distinguished from reminder buying in that the shopper has no prior knowledge to assist her in the purchase.

Adelaar (2003) further notes on this dimension saying that, considering Stern's four categories of impulse buying, suggestion impulse buying is the relevant one in an on-line media environment since it enables consumers to seek additional information and eventually to buy items directly online or off-line. An on-line environment can provide an appropriate venue for acting upon the buying impulse. 
Ertemel, A.V., Başç1, A. (2015). Effects of Zero Moment of Truth on consumer buying decision: An exploratory research in Turkey. International Journal of Social Sciences and Education Research, 1 (2), 526-536.

Therefore, our proposition in this paper is that any information search behavior in online medium prior to product purchase decision is attached to suggestion impulse buying behavior, which is the base of Zero Moment of Truth (ZMoT) concept.

Stern's conceptualization of impulse purchasing is based on the premise that the making of an impulse purchase, be it planned, pure, reminder or suggestion, is linked to the consumer's exposure to a stimulus (e.g., "a shopper sees a product")

\section{Stimuli as the origin of impulse buying}

In the original conceptualization of impulse buying, the notion of the product as stimuli was a very important part of the definitions of types of impulse purchases. Applebaum (1951) suggested that impulse purchasing might stem from the consumer's exposure to sales promotion stimulus. Wolman (1973) defines an impulse as not consciously planned, but arises upon confrontation with a certain stimulus. Kroeber-Reil (1980) also argues that impulse buying is reactive behavior and often involves an immediate action response to a stimulus. Impulse purchasing may occur as a result of marketer's environmental manipulations through atmospherics (Kotler 1974), merchandising stimuli such as retail shelf location (Rook, 1987),

Childers et al. (2001) suggest, if shoppers believe that the sensory information available via the interactive media is sufficient, there is reason to believe that the shoppers will enjoy using the new media for web-shopping. Following Kotler's (1974) observation that impulse purchasing may occur as a result of marketer's environmental manipulations through atmospherics, there is a possibility that "webmosphirics" which according to Childers et al. (2001) represents the virtual environment counterpart to the physical surroundings associated with the retail atmosphere (such as graphics, text, pop-up windows, search engine configuration, audio, color, streaming video, and organization and grouping of merchandise), may lead to impulse buying.

\section{Moments of truth}

There is a long tradition in service research to acknowledge the service encounter (i.e., the person-to-person encounter between a customer and a firm's representative) as important for the overall success of the service firm (Solomon et al., 1985) Hence, this encounter is sometimes referred to as the moment of truth (Normann, 2000).

Coming from this notion, Moments of Truth (MOT), in marketing, can be described as instances of contact between a consumer and a brand that gives the consumer an opportunity to form an impression about the brand in question. They are crucial instances in which a brand encounter captivates, delights or disinterests potential customers.

Procter \& Gamble saw the critical importance of the seven seconds after a shopper first encounters a store shelf. Hence, they labeled this at the shelf decision moment as the "First Moment of Truth" (FMOT) (Nelson, Ellison, 2005). 
Ertemel, A.V., Başç1, A. (2015). Effects of zero moment of truth on consumer buying decision: An exploratory research in Turkey. International Journal of Social Sciences and Education Research, 1 (2), 526-536.

Figure 1. 3 Traditional step mental model of decision making process

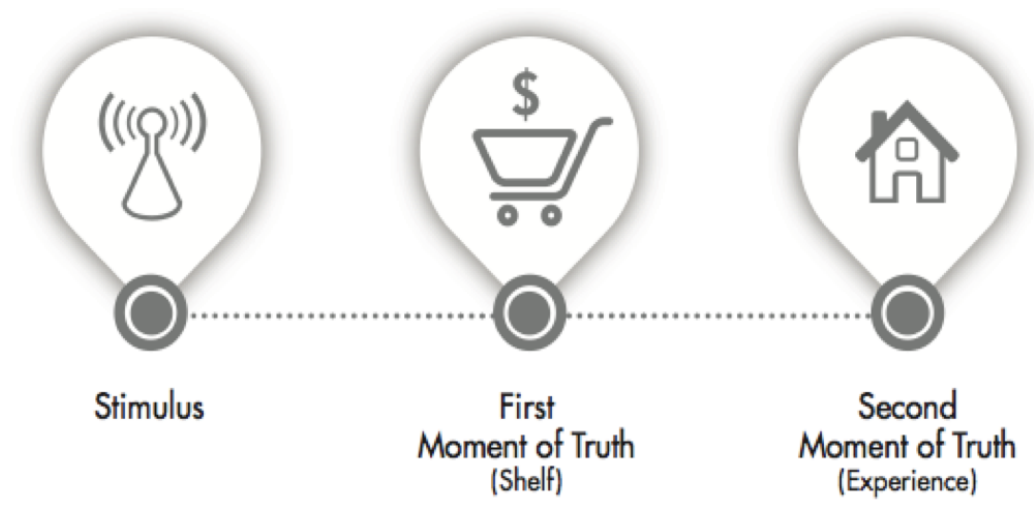

Source: Google ShopperSciences Research, 2011

Actual use of the product—or experiencing the brand—is known as the "Second Moment of Truth" (SMOT). Procter \& Gamble CEO, Lafley described the new challenge of brands as winning two moments of truth. The first moment occurs at the store shelf, when a consumer decides whether to buy one brand or another. The second occurs at home, when she uses the brand - and is delighted, or isn't.

In recent years, with the advent of smartphones consumers start to learn more about the considered products at the time of stimulus. They start experiencing the products first in digital world. Many consumers use the internet to collect information on products and brands before making purchases offline (Venkatesan et al. 2007; Teltzrow et al. 2007).

Digital technologies are changing consumer behavior and enabling the creation of a credible, consumer-led information cycle. Digitally empowered consumers actively search online for brand and market information ahead of making purchase decisions. Those interactions constitute new "Moments of Truth" (MOT) between brands and consumers that are not accounted for before.

Figure 2. The new mental model of decision making process

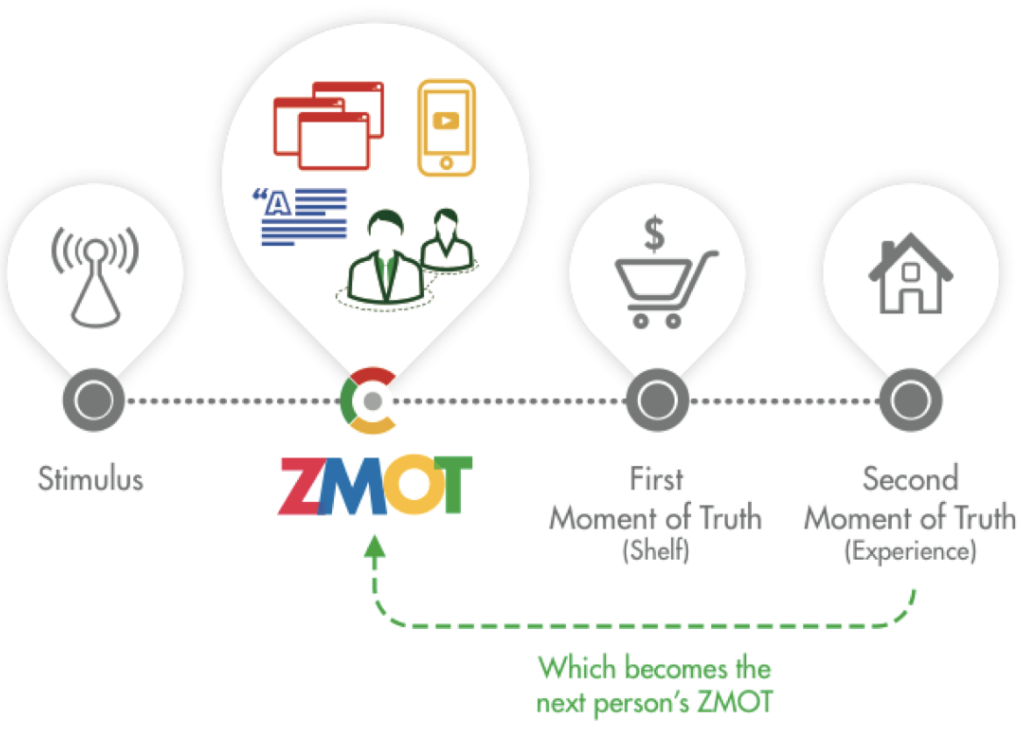

Source: Google ShopperSciences Research, 2011 
Ertemel, A.V., Başç1, A. (2015). Effects of Zero Moment of Truth on consumer buying decision: An exploratory research in Turkey. International Journal of Social Sciences and Education Research, 1 (2), 526-536.

Consumer behavior is changing in the light of advancing digital capabilities. The importance of online recommendations is more significant as consumers turn to their peers and user generated content (reviews, ratings etc.) - rather than marketers - for brand information. As consumers share their experiences online, this information becomes available to other consumers either through interpersonal connections, searchable results or suggestions.

This new phenomenon is called Zero Moment of Truth (ZMOT), which is the moment consumers are exposed to a stimulus and readily grabs his smartphone, laptop, tablet etc. to seek credible $3^{\text {rd }}$ party information online about what they are looking for. First use of the term Zero Moment of Truth was by IRI Group (Symphony, IRI, 2009). The term was made popular with the book Winning the Zero Moment of Truth published by Google (2012) before a purchase decision is made. Moments of Truths created following a brand experience produce both positive and negative user generated content, which increasingly are being indexed to appear in search-engine results - and represent an initial moment of truth (ZMOT) for information seeking consumers.

\section{The importance of Zero Moment of Truth}

A prior research studying Zero Moment of Truth questioned where influence takes place as shoppers move from undecided to decided (Lecinski, 2011)

The results showed that the average shopper used 10.4 sources of information to make a decision in 2011 which was 5.3 in a similar study conducted in 2010. It was also found that $84 \%$ of the decision makers used online sources to guide them and that $54 \%$ of consumers comparisonshopped for products online. These results support the fact that zero moment of truth is becoming more and more important in consumer decision process.

The primary defining characteristics of ZMoT are;

- ZMoT takes place in online medium (i.e. search engines).

- ZMoT takes place in real time, at any time of the day. Increasingly, it happens on the go with smartphones as the consumers are exposed to a stimulus.

- The conversation is multi directional - brands, friends, strangers and experts all have their say and compete for attention.

\section{Research model}

This paper aims at making an exploratory research examining the altered consumer decision process upon Turkish consumers in the following dimensions;

- Compare ZMoT against first moment of truth and second moment of truth

- Analyze whether ZMoT phenomenon has significant differences with regard to different sectors

- $\quad$ Analyze ZMoT based on different demographic variables

The research is important in the following aspects;

- Such a research has not been conducted in Turkey before 
Ertemel, A.V., Başç1, A. (2015). Effects of zero moment of truth on consumer buying decision: An exploratory research in Turkey. International Journal of Social Sciences and Education Research, 1 (2), 526-536.

- In today's modern communication environment where internet plays a significant role in decision making process, the research might shed some light to marketing practitioners in formulating their strategy for better understanding of altered consumer behavior.

- It will give insight on further research ideas.

\section{Research method and limitations}

The research is limited to consumers living in Turkey who have recently had a shopping experience in the past 3 months. It is further limited those who have been employed in a full time job, actively using Internet and aged between 18 and 65 . The research is conducted to as an exploratory research on 384 surveyors. Survey questions are obtained from a similar study conducted in US (Google, 2011).

The variables used in previous study based on different phases of buying process are listed below:

\section{Stimulus}

Noticed advertising while browsing online

Saw/tried product at the house of a friend/family member

This is a brand I grew up with

Looked at/read magazine advertisements

Saw an ad on an outdoor billboard

Read magazine articles/reviews/information

Saw an ad in a newspaper/newspaper insert

Read newspaper articles/reviews/information

Looked up brands/retailers in the Yellow Pages

Attended a show or event where product were featured

Received mail at home from a brand/manufacturer (e.g., catalogue, brochure)

Received mail at home from a store/retailer (e.g., catalogue, brochure)

Read information in an email received from a brand/manufacturer

Read information in an email received from a retailer/store

Tried a sample/experienced the product at a special event

Heard it discussed on the radio

Saw advertisements on television

Watched a TV show that featured the product

ZMoT (Zero Moment of Truth)

Talked with friends/family about the product 
Ertemel, A.V., Başçı, A. (2015). Effects of Zero Moment of Truth on consumer buying decision: An exploratory research in Turkey. International Journal of Social Sciences and Education Research, 1 (2), 526-536.

Searched online, used a search engine

Comparison shopped products online

Sought information from a product brand/manufacturer website Read product reviews or endorsements online

Sought information from a retailer/store website

Read comments following an article/opinion piece online

Became a friend/follower/"liked" a brand

Watched videos about product online

Read/visited a blog that discussed product

Searched the web for information with my mobile phone before shopping

Talked to a customer service representative online

Searched the web for information with my mobile phone in the store

Saw product mentioned on a social networking website like Facebook

Received a referral notice from a friend online

Commented on a product mentioned on a social networking website like

Facebook Received a coupon or pricing information from someone on a social networking site

Commented on a blog that discussed product

Searched for a coupon with my mobile phone before shopping

Saw an ad/coupon sent to my mobile phone

Looked for coupons on a retailer/store website

Received a text from a brand/manufacturer on my mobile phone

Searched for a coupon with my mobile phone in the store

Looked for coupons on a product brand/manufacturer website

Participated in a chat or discussion online about product

Used my mobile phone to scan 2D barcode/QR code in the store

Read/visited a forum/message board about product

Talked to a customer service rep/salesperson via email

Commented on a forum/message board about product

\section{FMoT (First Moment of Truth)}

Tried a sample/experienced the product in a store

Talked with a salesperson or associate in the store

Talked with a customer service representative on the phone 
Ertemel, A.V., Başç1, A. (2015). Effects of zero moment of truth on consumer buying decision: An exploratory research in Turkey. International Journal of Social Sciences and Education Research, 1 (2), 526-536.

Looked at the product package in the store

Read brochure/pamphlet about the product in the store

Used product coupon I got at the store

Used computer in the store to look up information on product

Used a loyalty card/frequent buyer card

Redeemed a gift card/rewards card

\section{SMoT (Second Moment of Truth)}

Mentioned it to friends/family

Mentioned it to a co-worker

Took a survey

Wrote a customer review on a website

Wrote about it on a Facebook page Posted Tweets about it

Wrote about it in a blog

The translation of the questionnaires from English into Turkish was conducted by following standard procedures used in intercultural research.

\section{Results}

The survey results were analyzed both across different sectors and demographic and information.

Figure 3. Survey Results Based on Gender

\section{Decision Making Process Based on Demographic Information}

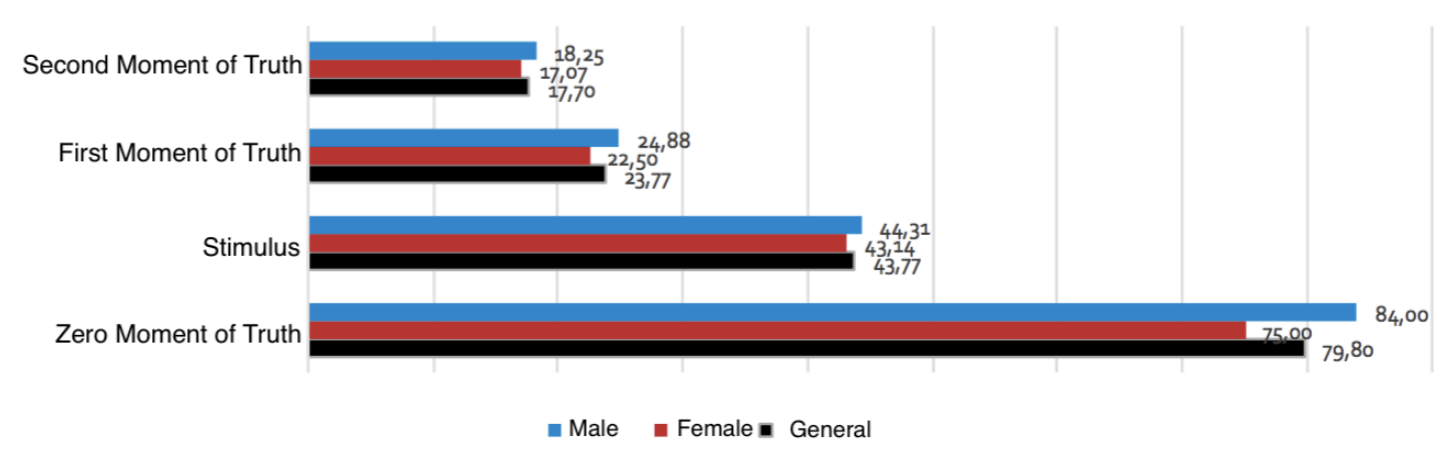

The results indicate that ZMoT is most significant phase among all phases in consumer decision process. The following table depicts the analysis of moments across sectors: 
Ertemel, A.V., Başçı, A. (2015). Effects of Zero Moment of Truth on consumer buying decision: An exploratory research in Turkey. International Journal of Social Sciences and Education Research, 1 (2), 526-536.

Figure 4. Analysis of moments across different sectors

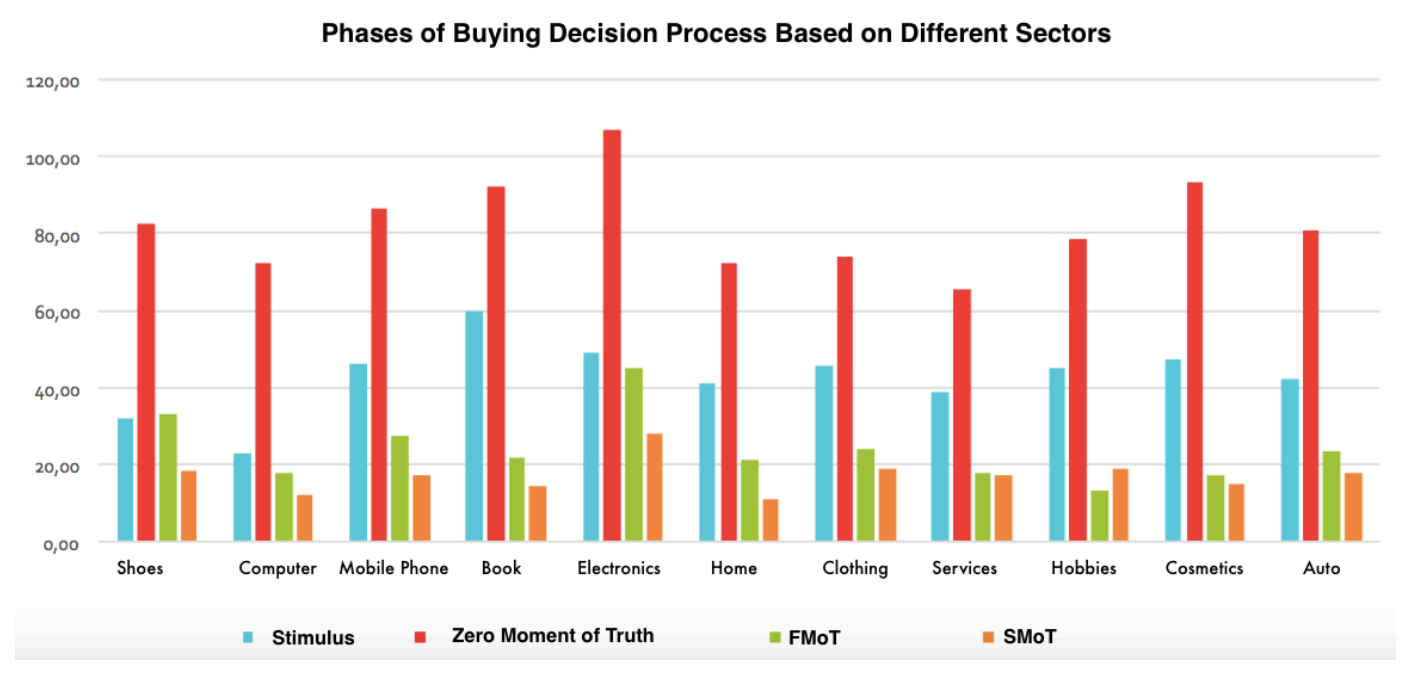

\section{Discussion}

Based on the survey results, Zero Moment of Truth, in which consumers' Internet based research take place, acts as the most determining phase in decision making process. In addition, as seen in the Figure 3, it seems that male respondents favor ZMoT more than females in their decision making process. When the results are analyzed across different sectors, it's found that ZMoT is the most important phase across all sectors in buying decision-making process. Across all the sectors studied, electronics sector scores the highest and services sector scores the lowest rank.

\section{Conclusion and implications for future research}

Internet revolution gave rise to democratization of information where consumers not only have ready and more transparent access to all kind of information about the brands, anytime and anywhere using smartphones, they can also influence and be influenced by peers' opinions via user generated content. This new communication environment permanently alters buying decision process which takes into account the moment of truth after being exposed to a stimuli - including the consumers' online product research on search engines, online videos, social media posts, peer reviews etc, before going to the product shelf - the phenomenon called as Zero Moment of Truth.

This paper links this recent phenomenon coined by practitioners to already existing literature on the concept that has its roots in suggestive impulse buying phenomenon. Having discussed the theoretical foundation, a research is conducted on Turkish consumers to examine the relative importance of the altered phases in decision-making process. It has been discovered that ZMoT phase is significantly important in buying process across all sectors being examined. Further, electronics category found to be influenced most, and services sector found to be influenced least by ZMoT.

This exploratory research served as the first of its kind in Turkey. The research can be extended further with different demographic variables and among other sectors. This way, more insights can be obtained about consumer buying decision process in today's communication environment. As a further research idea, this newly theorized Zero Moment of Truth phenomenon can also be studied in relation to brand preference, brand switching intention and behavior, customer loyalty and customer complaint management issues. 
Ertemel, A.V., Başç1, A. (2015). Effects of zero moment of truth on consumer buying decision: An exploratory research in Turkey. International Journal of Social Sciences and Education Research, 1 (2), 526-536.

\section{References}

Adelaar, T., Chang, S., Lancendorfer, K. M., Lee, B., \& Morimoto, M. (2003). Effects of media formats on emotions and impulse buying intent. Journal of Information Technology, 18(4), 247-266.

Applebaum, W. (1951). "Studying Consumer Behavior in Retail Stores", Journal of Marketing, Vol. 16, October, pp. 172- 178.

Beatty, S. E. and Ferrell M. E. (1998). "Impulsive Buying: Modeling Its Precursors", Journal of Retailing, Vol. 74 No. 2, pp. 169-191.

Childers, T.L., Carr C.L., Peck J., and Carson S. (2001). "Hedonic and utilitarian motivations for online retail shopping behavior”, Journal of Retailing, Vol. 77, 2001, pp. 511-535.

Clover, V. T. (1950). "Relative Importance of Impulse Buying in Retail Stores”, Journal of Marketing, Vol. 25, July, pp. 66- 70 .

Cobb, C. J. and Hoyer W. D. (1986). "Planned Versus Impulse Purchase Behavior”, Journal of Retailing, Vol. 62, Winter, pp. 67-81.

DuPont de Nemours and Co. 1945, 1949, 1959, 1965. Consumer Buying Habits Studies

Donthu, N. and Garcia A. (1999). “The Internet Shopper”, Journal of Advertising Research, 1999, pp. 5258.

Engel, James F. and Roger D. Blackwell (1982). "Consumer Behavior," Hinsdale, IL: Dryden Press.

Gabisch, J. A. (2011). Virtual world brand experience and its impact on real world purchasing behavior. Journal of Brand Management, 19(1), 18-32.

Google. " Shopper Sciences Zero Moment of Truth Macro Study ", U.S., 2011

Hausman, A. (2000). "A multi-method investigation of con- sumer motivations in impulse buying behavior”, Journal of Consumer Marketing, Vol.17 No.5, pp. 403-417.

Lecinksi, J. (2011). Winning the zero moment of truth. Zero Moment of Truth.

Kotler, P. (1974), "Atmospherics as a Marketing Tool," Journal of Retailing, Vol. 49, 4, (Winter), 48-64.

Kroeber-Rile, W. (1980). Konsumentenverhalten, Munich: V ahlen.

Nelson, Ellison. Wall Street Journal, 21 Sept, 2005, http://online.wsj.com/article/0,,SB112725891535046751,00.html

Normann, R., (2000). Service Management. Wiley, New York.

Puri, R. (1996). "Measuring and Modifying Consumer Impul- siveness: A Cost-Benefit Accessibility Framework", Journal of Consumer Psychology, Vol.5 No. 2, pp. 87-113.

Rook, D. W. and Fisher R. J. (1995), “Normative Influences on Impulsively Buying Behavior”, Journal of Consumer Re-search, Vol. 22, December, pp. 305-313.

Rook, D. W. and Hoch S. J. (1985). "Consuming Impulses”, Advances in Consumer Research, Vol. 12, eds. Morris B. Holbrook and Elizabeth C. Hirschman, provo, UT: Associa- tion for Consumer Research, pp. 23-27.

Rook, D. W. (1987). “The Buying Impulse”, Journal of Consumer Research, Vol.14, September, pp. 189199.

Rook, D. W. and Gardner M. P. (1993). “In the Mood: Impulse Buyings' Affective Antecedents", pp. 1-28 in Janeen Arnold-Costa and Russell W. Belk (Eds.), Research in Consumer Behavior, Vol. 6, Greenwich, CT: JAI press. 
Ertemel, A.V., Başç1, A. (2015). Effects of Zero Moment of Truth on consumer buying decision: An exploratory research in Turkey. International Journal of Social Sciences and Education Research, 1 (2), 526-536.

Solomon, M.R., Surprenant, C., Czepiel, J.A., Gutman, E.G. (1985). A role theory perspective on dyadic encounters: the service encounter. Journal of Marketing 49 (Winter), 99-111.

Stern, H. (1962). “The Significance of Impulse Buying Today”, Journal of Marketing, Vol. 26, April, pp. 59-63.

Symphony IRI Group report in October (2009). "Zero-Moment of Truth: Redefining the Consumer Decision-Making Process."

Venkatesan, R., V. Kumar, and N. Ravishanker (2007). "Multichannel Shopping: Causes and Consequences," Journal of Marketing, Vol. 71, No. 2: 114-132

Wolman, B. (1973). Dictionary of Behavioral Science, New York: Van Nostrand Reinhold

West, J.C. (1951). "Results of Two Years of Study into Impulse Buying," Journal of Marketing, 15 (January), 362-363. 